\title{
Structure and function of a cysBJIH gene cluster in the purple sulphur bacterium Thiocapsa roseopersicina
}

\author{
Thomas Haverkamp and Jens D. Schwenn
}

Biochemistry of

Plants/Faculty of Biology,

Ruhr University Bochum,

44780 Bochum, Germany
Author for correspondence: Jens D. Schwenn. Tel: +49234 7003657. Fax: +492347094396. e-mail: jens-dirk.h.schwenn@ ruhr-uni-bochum.de

\begin{abstract}
A gene cluster containing homologues of the genes cysB, cysJl and cysH was found in the genome of the sulphur-oxidizing purple bacterium Thiocapsa roseopersicina. The nucleotide sequence indicated four open reading frames encoding homologues of 3'-phosphoadenylylsulphate (PAPS) reductase (CysH), sulphite reductase flavoprotein (CysJ) and haem protein (CysI) subunits, and a transcriptional regulator (CysB). Genes cysJIH are separated by a short cisactive intergenic region from cysB which is transcribed divergently. cysB encodes a polypeptide of $35.9 \mathrm{kDa}$ consisting of 323 amino acid residues with $40 \%$ identity to the CysB regulator from enterobacteria. cysH encodes a protein with 239 amino acid residues and a calculated mass of $27.7 \mathrm{kDa}$; cys encodes a protein with 522 amino acid residues and a mass of $57.8 \mathrm{kDa}$; and cysl encodes a protein with 559 amino acid residues and a mass of $62.3 \mathrm{kDa}$. The cysJIH gene products have been expressed and used for complementation of cys mutants from Escherichia coli Biochemical analysis. The gene product CysH is a thioredoxin-dependent PAPS reductase (EC 1.8.99.4). It was repressed under photoautotrophic growth using hydrogen sulphide as electron donor and derepressed under conditions of sulphate deficiency. Products of the cys/l genes were identified as the two subunits of NADPH-sulphite reductase (EC 1.8.1.2). cysJ encoded the flavoprotein, with $\geq 39 \%$ identity to the protein from $E$. coli, and cysl encoded the haem protein, with $\geq 53 \%$ identity. A cysl clone was used to complement the corresponding mutant from $E$. coli and to express enzymically active methylviologen-sulphite reductase.
\end{abstract}

Keywords: sulphate-oxidizing bacterium, cysteine biosynthesis, phosphoadenylylsulphate (PAPS) reductase, sirohaem sulphite reductase, thioredoxin

\section{INTRODUCTION}

Assimilation of sulphate depends on a set of five enzymes which successively activate sulphate to an adenylylated form (3'-phosphoadenylylsulphate, PAPS) before it is reduced to sulphite and to sulphide. The main function of this pathway is to produce sulphide for the biosynthesis of amino acids. Sulphate dissimilation is described for sulphate-reducing bacteria which reduce sulphate to sulphide under anaerobic conditions using hydrogen or carbohydrates as electron donor. This respiratory reduction of sulphate is often coupled to

Abbreviations: APS, adenylyl sulphate; $\mathrm{MVH}$, methylviologen, reduced form; PAPS, 3'-phosphoadenylyl sulphate.

The EMBL accession numbers for the sequences reported in this paper are Z23169 and U75512
ATP synthesis (Kelly, 1990). Hydrogen sulphide and other reduced forms of sulphur are used by chemolithotrophic bacteria and photoautotrophic purple or green sulphur bacteria as electron donors for chemo- or photosynthetic reduction of carbon dioxide (Pfennig $\&$ Trüper, 1992). These organisms oxidize sulphur compounds such as sulphide or thiosulphate to sulphate. Sulphite is the pivotal intermediate in the oxidative reactions as it is in the reductive reactions, although many patterns of sulphur oxidation may be more complex than anticipated by a simple reversal of the reductive steps (Kelly et al., 1997; Friedrich, 1998).

Assimilatory sulphite reductases can reduce sulphite to sulphide in a single step consuming six electrons, which can be provided from NADPH or reduced ferredoxin. This reduction is dependent on the occurrence of sirohaem in combination with iron-sulphur cluster(s) as 
cofactors (Siegel, 1976; Crane \& Getzoff, 1996). Both cofactors require two special pairs of cysteines that bind an orthorhombic $\mathrm{Fe}_{4}-\mathrm{S}_{4}$ cluster. Sirohaem is bound by ionic forces provided by the carboxyl groups and basic amino acid sidechains of the polypeptide backbone; one of the cysteines is also used to couple the haem with the $\mathrm{Fe}_{4}-\mathrm{S}_{4}$ cluster. Although virtually scattered over the entire apoprotein, residues shown to be involved in the binding of sirohaem are highly conserved among NADPH-sulphite reductases and ferredoxin-sulphite and nitrite reductases. Their role as haem ligands was elucidated most recently by the high-resolution threedimensional structure of the haem protein of sulphite reductase from Escherichia coli (Crane \& Getzoff, 1996; Crane et al., 1997). Of the two pairs of cysteines required for the binding of the $\mathrm{Fe}_{4}-\mathrm{S}_{4}$ clusters, the first pair is found in a highly conserved CNPGC cysteine pentapeptide, and the second in a more variable $\mathrm{CX}_{5} \mathrm{C}$ cysteine heptapeptide. C483 in the pentapeptide CNPGC of $E$. coli sulphite reductase is used as the bridging ligand between the iron-sulphur cluster and the central Fe of the haem, while the remaining three cysteine residues exclusively bind the $\mathrm{Fe}_{4}-\mathrm{S}_{4}$ cluster. The unique combination of cofactors is found in assimilatory sulphite reductases and nitrite reductases alike, suggesting that the apoprotein forms a highly conserved structure. Using the haem protein of NADPH-sulphite reductase as threedimensional model, Crane et al. (1995) showed that functionally important subdomains of ferredoxin-sulphite and ferredoxin-nitrite reductase can be superimposed to give nearly identical structures.

At the beginning of this investigation, we assumed that this structure is encoded by related structural genes. Indeed, by using a DNA fragment of the $c y s I$ gene from E. coli as probe, and by nested PCR using degenerate primers deduced from conserved regions of the polypeptide, we isolated the ferredoxin-sulphite reductase gene from the cyanobacterium Synechococcus (Gisselmann et al., 1993) and a higher plant (Brühl et al., 1996). As a first step in dissecting the identity and function of sulphite reductases in the purple bacterium Thiocapsa roseopersicina the genome was probed with a 64-fold degenerate oligonucleotide deduced from the conserved cysteine pentapeptide CPNGC of assimilatory sulphite reductase (Haverkamp, 1992, 1996; Gisselmann et al., 1993). In the present paper we report that the structural gene of this putative sulphite reductase is found in a complex gene cluster consisting of four open reading frames (ORFs) encoding a cysB-like regulator, a PAPS reductase encoded by a $c y s H$ homologue and a sirohaem sulphite reductase encoded by homologues of $c y s J$ and $c y s I$. The genes were sequenced and characterized by phenotypic complementation of corresponding $c y s$ mutants from $E$. coli and analysed for functionally active gene products.

\section{METHODS}

Bacterial strains and plasmids. The bacterial strains, plasmids and DNA fragments used in this study are listed in Table 1. T. roseopersicina was grown phototrophically at $500 \mathrm{~lx}$
(21 $\mathrm{mE} \mathrm{m}^{-2} \mathrm{~s}^{-1}$ ) in modified medium 1 (Pfennig \& Trüper, 1992), replacing $\mathrm{MgSO}_{4}$ by $\mathrm{MgCl}_{2}$ and SL12 by SL4. Strain M1 was supplemented with $25 \mathrm{~g} \mathrm{NaCl}^{-1}$. Sulphide/bicarbonate feeder solution was prepared as described by Siefert \& Pfennig (1984). For phototrophic growth the basal mineral medium [containing, per litre: $0.5 \mathrm{~g} \mathrm{KH}_{2} \mathrm{PO}_{4}, 0.62 \mathrm{~g} \mathrm{~K}_{2} \mathrm{HPO}_{4}, 0.5 \mathrm{~g}$ $\mathrm{NH}_{4} \mathrm{Cl}, 0.33 \mathrm{~g} \mathrm{KCl}, 0.05 \mathrm{~g} \mathrm{CaCl}_{2} .2 \mathrm{H}_{2} \mathrm{O}, 0.33 \mathrm{~g} \mathrm{MgCl}_{2} . \mathrm{H}_{2} \mathrm{O}$ (Kämpf \& Pfennig, 1980)] was supplemented with $1 \mathrm{ml} \mathrm{SL} 4 \mathrm{I}^{-1}$ and $20 \mu \mathrm{g}$ vitamin $\mathrm{B} 12 \mathrm{l}^{-1}$, and adjusted to $\mathrm{pH} 7 \cdot 3$. A mixture of organic substrates was added to give a $2 \%(\mathrm{v} / \mathrm{v})$ final concentration. The mixture consisted of sucrose, galactose, mannitol, glucose, fructose, 2-oxoglutarate, pyruvate, actetate, succinate and malate at $10 \mathrm{~g} \mathrm{l}^{-1}$ per compound in $\mathrm{H}_{2} \mathrm{O}$, adjusted to $\mathrm{pH} 7 \cdot 0$ using $\mathrm{KOH}$ and sterilized by filtration. For anaerobic growth 1 litre screw-capped bottles were filled completely but semioxic cultures were grown on a shaker $\left(120\right.$ r.p.m. at $\left.30^{\circ} \mathrm{C}\right)$ using notched 1 litre Erlenmeyer flasks half-filled and sealed with foam plastic plugs.

$E$. coli host strains were grown on LB supplemented with $100 \mu \mathrm{g}$ ampicillin $\mathrm{ml}^{-1}$ and/or $10 \mu \mathrm{g}$ tetracycline $\mathrm{ml}^{-1}$ if required for selection of transformed strains. In addition to the individual growth requirements, we grew the cyscomplemented mutants on VBB medium (Vogel \& Bonner, 1956) or supplemented with cysteine at $1 \mathrm{mM}$.

Cloning methods. Phage EMBL3 was used to construct a library harbouring genomic DNA from $T$. roseopersicina M1. DNA was partially restricted with SauIIIA and sizefractionated ( $15 \mathrm{~kb}$ average size) before ligation into the BamHI site of EMBL3. We used E. coli LE392 as host. It was transfected using a $\lambda$ coat packaging kit (Promega, Packagene in vitro). Plating, lysate preparation and isolation of DNA followed the methods outlined by Sambrook et al. (1989). For DNA sequencing the dideoxy chain-termination method (Sanger et al., 1977) was used. Compressed sites were analysed with 7-deaza-dGTP mixes (Pharmacia) and universal primers (T3 and T7), and synthetic oligonucleotides were used for primer-hopping to sequence template and non-template strands.

The CPNGC-specific R3 oligonucleotide used as probe is described by Brühl et al. (1996). חive cys-positive clones were detected among 50000 plaques, and subclones in pBluescript II $\mathrm{SK}+$ were analysed as described below.

Nucleotide and amino acid sequences were analysed using the software provided by servers of EMBL or NCBI (Altschul et al., 1997). Treeview 1.4 was written by R. Page, IBLS, University of Glasgow, UK

Gene products. $c y s J I, c y s H$ and $c y s B$ were expressed to allow their characterization by function and by immunological methods. Functionally active gene products were obtained by using pBTac1 (Boehringer) constructs; polypeptides required for the production of antibodies were produced from $p Q E$ vectors (Qiagen).

In order to express NADPH-sulphite reductase, cys $J$ from $T$. roseopersicina and cysG from Salmonella typhimurium were co-integrated into pBTac1. cys $G$ was excised from pJYW609 as a $2.34 \mathrm{~kb} \mathrm{ClaI-BamHI}$ fragment including its own promoter and blunt-end ligated into the PstI site yielding $\mathrm{pBTac} 1 c y s G$. pTH11 was constructed by insertion of an NdeI-Sall fragment (nt 582-4066) from pTH6 (5'-3'orientation) into pBTac1 cys $G$ using the $S m a$ I site, while pTH12 was constructed by using the ClaI-SalI fragment (nt 602-4066). Both constructs harboured the $c y s$ genes in the order $c y s J I:: c y s G$ under control of the tac promoter. pTH13 containing DNA that encoded the $\beta$-subunit of sulphite reductase was obtained from pTH12 by deleting the PstI fragment. 
Table 1. Strains and plasmids

\begin{tabular}{|c|c|c|}
\hline Strain or plasmid & Genotype & Source or reference \\
\hline \multicolumn{3}{|l|}{$T$. roseopersicina } \\
\hline M1 & Wild-type & $\begin{array}{l}\text { H. van Gemerden, RU } \\
\text { Groningen, Netherlands }\end{array}$ \\
\hline 6311 & Wild-type & $\begin{array}{l}\text { H. G. Trüper, Universität } \\
\text { Bonn, Germany }\end{array}$ \\
\hline \multicolumn{3}{|l|}{ E. coli } \\
\hline JM96 & $\begin{array}{l}\text { thr-1 leuB6 trp-1 bisG1 cysH56 argH1 thi-1 ara- } \\
13 \text { lacY1 gal-6 malA1 xyl-7 mtl-2 strA9 tonA2 } \\
\lambda^{\mathrm{R}} \lambda^{-} \text {supE44 }\end{array}$ & $\begin{array}{l}\text { Genetic Stock Center, } \\
\text { Yale, \#5746 }\end{array}$ \\
\hline JM96 $6_{\mathrm{FAK}}$ & As JM96 but $h s d R 2 z j j-202:: \operatorname{Tn} 10\left(\mathrm{Tet}^{\mathrm{R}}\right)$ & Krone et al. (1991) \\
\hline JM246 & cysl53 $\lambda^{-} \mathrm{IN}(r r n D-r r n E) 1$ & $\begin{array}{l}\text { Genetic Stock } \\
\text { Center, Yale, \#5747 }\end{array}$ \\
\hline AT713 & $\begin{array}{l}\text { supE44? } \hat{\lambda}^{-} \text {cysj43 argA21 lysA22 rpsL104 } \\
\text { malA1 }\left(\lambda^{\mathrm{R}}\right) \text { xyl-7, mtl-2, thi-1? }\end{array}$ & $\begin{array}{l}\text { Genetic Stock Center, } \\
\text { Yale, \#4529 }\end{array}$ \\
\hline LE392 & e14 (McrA) hsdR514 supE44 supF58 lacY1 & Stratagene \\
\hline XL-1 Blue & $\begin{array}{l}\text { recA1 endA1 gyrA96 thi-1 bsdR17 supE44 relA1 } \\
\text { lac }\left[\mathrm{F}^{\prime} \text { proAB } \text { lacl }^{\mathrm{q}} \mathrm{Z} \Delta \mathrm{M} 15 \mathrm{Tn} 10\left(\mathrm{Tet}^{\mathrm{R}}\right)\right]\end{array}$ & Stratagene \\
\hline TG1 & $\begin{array}{l}\text { supE hsd } \Delta 5 \text { thi } \Delta(\text { lac-pro } A B) \mathrm{F}^{\prime}(\text { traD } 36 \text { proAB } \\
\left.\text { lacI }^{+} \text {lac } \mathrm{Z} \Delta \mathrm{M} 15\right)\end{array}$ & Laboratory collection \\
\hline \multicolumn{3}{|l|}{ Plasmids } \\
\hline pBluescript II & $2.96 \mathrm{~kb}$ phagemid & Stratagene \\
\hline $\mathrm{pBTac1}$ & $4.6 \mathrm{~kb}$ tac vector & Boehringer Mannheim \\
\hline pQE30, 31, 32 & $\mathrm{His}_{6}$ fusion expression vectors & Qiagen \\
\hline pJYW609 & $\mathrm{pBR} 322:: c y s J I^{\mathrm{Ec}}+c y s G^{\mathrm{st}}$ & Wu et al. (1991) \\
\hline pUB5 & pBTac1::cys $H^{\mathrm{Ec}}$ & Berendt et al. (1995) \\
\hline pQEB1 & pQE30::cysB(SacI 131-PstI 545) & This work \\
\hline pQEB11 & pQE30::cysB $(K p n I-H i n d I I I) *$ & This work \\
\hline pQEJ6 & pQE31::cysJ(PstI 666-PstI 1794) & This work \\
\hline pQEI3 & pQE32::cysI (BglII 3278-KpnI 4225) & This work \\
\hline PQEH & pQE30: : cysH(BamHI-HindIII $)^{*}$ & This work \\
\hline pTH1 & pBS: :cyslH(BamHI 3295-5170) & This work \\
\hline $\mathrm{pTH} 2$ & pBS: : cysHI (BamHI 5170-3295) & This work \\
\hline pTH3 & pBS: :cys II(BamHI 1129-3127) & This work \\
\hline pTH4 & pBS: :cysIJ(BamHI 3127-1129) & This work \\
\hline pTH5 & pBS::cysIH(S1:3720-BamHI 5157) & This work \\
\hline pTH6 & pBS: : cysBJIH(SalI 1-4066) & This work \\
\hline $\mathrm{p}$ TH7 & pBS: :cysHIJB(SalI 4066-1) & This work \\
\hline pTH8 & pBS : : cysBJ(BamHI-BamHI 1129)† & This work \\
\hline p TH9 & pBS : :cysJB(BamHI 1129-BamHI)† & This work \\
\hline pTH10 & pBS: $c y s J-n a r K(B c l \mathrm{l} 4 \mathrm{~kb}$ genomic) & This work \\
\hline pBTac1cysG & $\begin{array}{l}\text { pBTac1: : cys } G^{\mathrm{st}}(\mathrm{ClaI} / \mathrm{BamHI}) \text { of } \mathrm{pJW} 609 \text { in } \\
\text { PstI site of pBTac1 }\end{array}$ & This work \\
\hline pTH11 & $\begin{array}{l}\text { pBTac: :cys } G^{\mathrm{st}}+\text { cysJI(NdeI 582-Sall 4066) in } \\
\text { Smal of pBTac1 }\end{array}$ & This work \\
\hline pTH12 & pBTac: : cys $G^{\mathrm{st}}+c y s J I(C l a \mathrm{I} 602-S a l \mathrm{I} 4066)$ & This work \\
\hline p TH13 & pBTac: : cys $G^{\mathrm{st}}+$ cys JI $(P s t \mathrm{I} 1794-\mathrm{SalI} 4066)$ & This work \\
\hline pKStrx1 & pBS::trx-rho (BamHI $2 \mathrm{~kb}$ genomic) & This work \\
\hline
\end{tabular}

"Restriction site introduced by PCR primer.

†Includes Bam $\mathrm{HI}$ site of the vector.

Active PAPS reductase that supported growth of $E$. coli JM96 $6_{\mathrm{FAK}}$ was expressed from a pBluescript II KS + derivative. The structural gene in pTH5 was contained in the bp 3720 5157 fragment obtained by $\mathrm{S} 1$ nuclease digestion of cysl up to bp 3720 and restriction with $\mathrm{BamHI}$. The $\mathrm{His}_{6}-\mathrm{CysH}$ fusion protein in $\mathrm{pQEH}$ was expressed from a PCR-amplified gene using cysH5 (3865: 5' GACTGGAT-CCATGAGTAAGCCCCGATC 3') and cysH3 (4561: 5' TCGCGGTACCGAAA- 
CTAACGATGC $3^{\prime}$ ) as primers. The $c y s B$ structural gene was isolated from a pBluescript II SK + plasmid containing a $4 \mathrm{~kb}$ $B c l$ I genomic fragment identified by hybridization with a $0.58 \mathrm{~kb}$ NdeI-SalI fragment of pTH6. Primers cysB5 (960: $5^{\prime}$ TCACGTACCAACGATATGGACGTACGCC 3') and cysB3 (4: 5' CGCGAAGCTTAAGCA-CGCCCTCAGTC 3') were used to amplify the gene and the resultant $K p n \mathrm{I} / \mathrm{HindIII}$ (pQEB11) clone was expressed as a $\mathrm{His}_{6}$ fusion protein in pQE30.

\section{Enzyme assays, purification and immunological methods}

Sulphite reductase. Frozen cells (23 g) from E. coli JM246 transformed with pTH3 and grown in VBB minimal medium (Vogel \& Bonner, 1956) were ruptured by passage through a French press at $14.4 \mathrm{MPa}$ using $50 \mathrm{mM}$ phosphate buffer $\mathrm{pH} 7 \cdot 7,2 \mathrm{mM}$ EDTA, $1 \mathrm{mM}$ PMSF, $0.05 \mathrm{mg} \mathrm{DNase} \mathrm{ml}^{-1}$ and $0.05 \mathrm{mg}$ lysozyme $\mathrm{ml}^{-1}$. Cell debris was removed by centrifugation at $40000 \mathrm{~g}$ for $20 \mathrm{~min}$. Active protein was recovered by fractionation with ammonium sulphate (from 40 to $90 \%$ saturation). It was collected by centrifugation and dialysed against $50 \mathrm{mM}$ Tris/ $\mathrm{HCl} \mathrm{pH} 7 \cdot 8,0 \cdot 1 \mathrm{mM}$ EDTA. Anionexchange chromatography on DEAE-Sepharose CL $6 \mathrm{~B}$ applying a gradient of $0-1 \mathrm{M} \mathrm{NaCl}$ in Tris/ $\mathrm{HCl}$ buffer was used to enrich the protein. The concentration of enzyme protein was followed by immunodot-blotting of the fractions and testing for sulphite reductase protein using rabbit anti-sulphite reductase IgG. Activity was measured as methylviologen (MVH)-dependent sulphide formation from sulphite in stoppered cuvettes made anaerobic by repetitive evacuation and flushing with deoxygenated nitrogen. $\mathrm{MVH}$ was added to start the reaction. It was collected from a $10 \mathrm{mM}$ stock solution in $50 \mathrm{mM} \mathrm{KH} \mathrm{PO}_{4} / \mathrm{K}_{2} \mathrm{HPO}_{4}$ buffer, $\mathrm{pH} 7 \cdot 7$, plus $0.1 \mathrm{mM}$ EDTA, reduced electrochemically (Schwenn \& Kemena, 1984). Sulphide was determined colorimetrically according to Siegel (1965).

PAPS reductase. The enzyme was measured as thioredoxindependent liberation of $\left[{ }^{35} S\right]$ sulphite from $\left[{ }^{35}\right.$ S $]$ PAPS using recombinant thioredoxin from $E$. coli (MBI Fermentas) and dithiothreitol as auxiliary reductant (Schwenn et al., 1988; Berendt et al., 1995). Rates were determined as $\mathrm{nmol}^{35} \mathrm{SO}_{3}^{-}$ (mg protein) ${ }^{-1} \mathrm{~min}^{-1}$ (Schwenn \& Schriek, 1986); [ $\left.{ }^{35} \mathrm{~S}\right] \mathrm{PAPS}$ was prepared enzymically from ${ }^{35} \mathrm{SO}_{4}^{-}$(Schriek \& Schwenn, 1984) and reaction products were analysed by HPLC (Schwenn \& Jender, 1980).

$\mathrm{His}_{6}$ fusion proteins and immunological methods. Rabbit polyclonal antisera were raised against $\mathrm{His}_{6}$ fusion proteins. Expression of the genes was induced by $0.4 \mathrm{mM}$ IPTG. The cells were extracted as described by the manufacturer (QIA-expressionist, Qiagen) using the protocol for insoluble proteins. For immunization the regimen of Catty \& Raykundalia (1988) was followed. The IgG fractions were recovered from whole antisera by anion-exchange chromatography and gel filtration as outlined. Protein-dye binding (Bradford, 1976), Western immunoblotting (Towbin et al., 1979) and SDS-PAGE (Laemmli, 1970) were used to assess the quality and purity of gene products as described earlier (Krone et al., 1991; Gisselmann et al., 1993).

\section{RESULTS}

\section{Structure of the $T$. roseopersicina cysBJIH DNA}

A $5157 \mathrm{bp}$ DNA fragment from $T$. roseopersicina containing four ORFs with homologies to cys gene products from entero- and cyanobacteria, yeast and higher plants was detected by Southern hybridization with an oligonucleotide deduced from a conserved region of assimilatory sulphite reductases (Ostrowski et al., 1989a, b; Gisselmann et al., 1993; Brühl et al., 1996). The relative size and orientation of the loci are depicted in Fig. 1. The ORFs represent homologues of the cysJI and cysH genes found in E. coli and Synechococcus. In $T$. roseopersicina the cys JIH homologues appear to form a multigene transcriptional unit which is separated by a non-translated intergenic region of $197 \mathrm{nt}$ from a $c y s B$ homologue. $c y s B$ is located upstream of $c y s J I H$ and transcribed from the $3^{\prime}-5^{\prime}$ strand in the opposite direction. Shine-Dalgarno sequences are found at position 591-595 for the cysJIH cistron and at position $415-420$ for $c y s B$. A Shine-Dalgarno sequence is missing upstream of cysI and translation of cysJ-cysI may be coupled. $c y s H$ posesses its own Shine-Dalgarno site at position C3838GGAGG. The start codon A3850TG of $c y s H$ is located upstream of the termination codon T3855AA of $c y s I$ so that $c y s I$ and $c y s H$ overlap by eight nucleotides and correct translation of $c y s H$ would require reinitiation and restart in a different reading frame. The intergenic region between $c y s B$ and the cysJIH cluster contains two putative promoter sequences (pcysB, T592TGGCA-N ${ }_{15}$-T571ATTCG; and pcys $J I H$, T444TCAAA- $\mathrm{N}_{18}$-T468ACACT) that are similar to the consensus sequence of the $\sigma^{70}$ promoters from E. coli. The intergenic region (Fig. 2) contains three palindromic sequences that could form stable hairpin structures (bp 507-535, bp 523-549 and bp 571-610). A small hairpin structure could form at position 4641-4665 of the sequence, with a $\Delta G$ of $-9.7 \mathrm{kcal} \mathrm{mol}^{-1}$ $\left(-40.6 \mathrm{~kJ} \mathrm{~mol}^{-1}\right)$. With its $\mathrm{G}$ : C-rich stem followed by a short run of Us, the structure resembles a rho-independent termination site; however, its function remains to be investigated.

\section{Structure and function of the gene products}

CysB : a transcriptional regulator. The $c y s B$ gene product consisted of 323 residues with a predicted molecular mass of $35939 \mathrm{Da}$. Its amino acid sequence shows an overall identity of $39.9 \%$ to that of the enterobacterial CysB proteins. Alignment of CysB from $T$. roseopersicina with its homologues from enterobacteria, including also two species of closely related rRNA superfamilies, produced three regions with a high degree of conserved residues that corresponded to the position of the coinducer recognition/response domains observed in the LysR family of transcriptional regulators (Schell, 1993). In T. roseopersicina S38 is replaced by T in a relatively poorly conserved area, whilst T148 is unchanged and located in a stretch of highly conserved amino acids. Mutation of S38 destroyed its DNAbinding capacity whereas replacement of the T148 caused constitutive expression of positively regulated genes of the cysteine regulon from S. typhimurium (Colyer \& Kredich, 1994).

CysJl: subunits of a flavo-haem sulphite reductase. cysJ encodes a polypeptide of 522 amino acids with a 


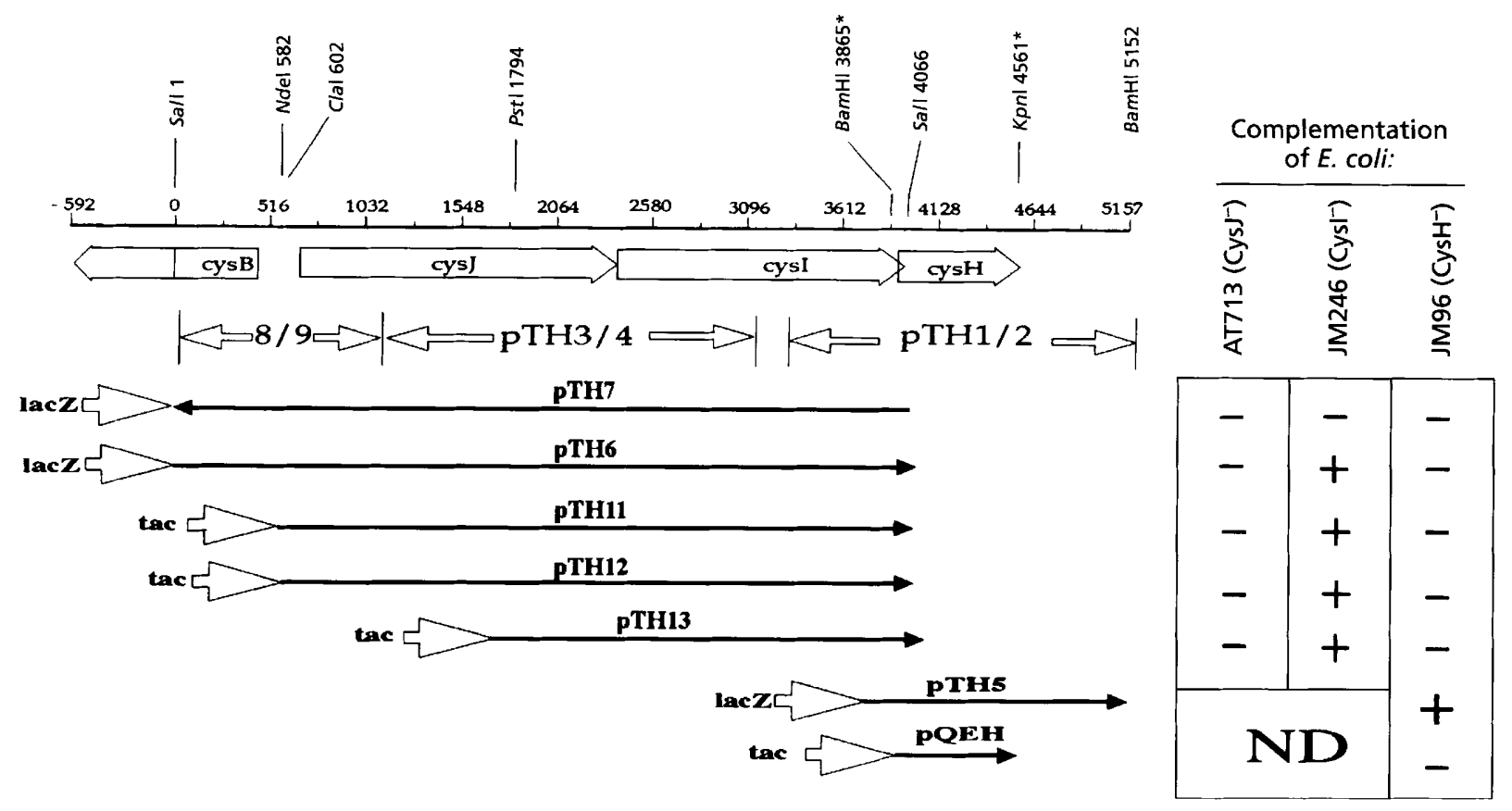

Fig. 1. ORFs of the $C y s B J I H$ multigene cluster and phenotypic complementation of $E$. coli cys mutants by $T$. roseopersicina cys homologues. The length, position and orientation of pTH subclones as obtained from the $5 \cdot 1 \mathrm{~kb}$ genomic DNA fragment in relation to the ORFs of the $c y s B J I H$ gene cluster are shown. Location of single restriction sites used for construction of the subclones is described in Table 1. lacZ and tac promoters were provided from pBTac1 and pBS cloning vectors; pTH1-7 are Bluescript derivatives; $\mathrm{pTH} 11,12$ and 13 are pBTac1 derivatives, and pQEH is a derivative of the pQE $\mathrm{His}_{6}$ tag expression vector. ND, Not determined (in the complementation tests).

accagcgaac gtaattggcg tacgtccata tcgttgcccg tgataacgac gcataaatgg TGOTCECTIG CATTAACOCC ATGCAGGIAt agcaacggge actattgCtg cgtatttacc

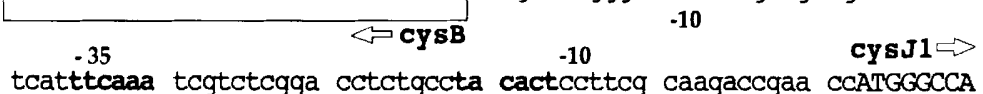
agtaaagttt agcagagcet ggagacggat gtgaggaagc gttctggctt ggtacccggt $-35$

AGCCCCACGG CACGGACCCG GACCCGGACC GAGCCGACCA CCCGGTCCGA ACCGACGCGA

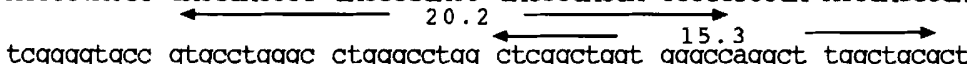
cysJ2 $\Rightarrow$

ACGCTCCGAA TACCAACGCA CGACATATGC CAAGAGATTT CGATCGATGG TICTTMCACA tgcgaggctt atggttgcgt gctgtatacg gttctctaaa gctagctacc aagaaagtgt
Fig. 2. Putative cis-active control region of the cysJlH gene cluster: promoters, ribosome-binding sites and secondary structures between the cys $B$ gene and the cys $J / H$ cluster. cys $/ 1$ and cys $/ 2$ indicate the position of the two possible start codons for cysJ. cys $B$ is located upstream of the cysJ/H cluster and transcribed divergently from the $3^{\prime}-5^{\prime}$ strand. A hypothesized promoter region of $C y s B$ overlaps with the transcriptional start region of cys/1 assuming a possible translational start at $A_{492}$ TG. Putative genes are boxed, the -35 -10 region is emphasized (bold lettering), and possible secondary structures are enclosed by arrows showing the $\Delta G$ values of formation (in kcal; $1 \mathrm{kcal}=4 \cdot 184 \mathrm{~kJ}$ ). molecular mass of $57791 \mathrm{Da}$. Comparison of the amino acid sequence with the sequences available [GenBank, PDB, SWISS-PROT and PIR (release 26.313)] aligned the cys J gene product with the $\alpha$ subunit of NADPHsulphite reductases from enterobacteria (score of 422 to 417). It shows $39 \cdot 3 \%$ identity to the $E$. coli flavoprotein of the assimilatory NADPH-sulphite reductase that binds FAD and FMN as prosthetic groups. The putative flavoprotein from $T$. roseopersicina is shorter than the enterobacterial flavoproteins by 69 amino acid residues when the entire sequence is considered. These missing residues cause three gaps in the second half of the sequence, where 59 residues are missing after T329, 21 residues after S343, and 5 residues after Q360. Additional amino acids are found in the first half of the polypeptide chain, where a small insertion of nine residues is found after N161 with no correspondence to the flavoproteins from E. coli and S. typhimurium. These differences in the primary structure apparently do not affect the flavin-binding domains. Of the typical sequence motifs that have been identified as prerequisites for binding the cofactors FMN, FAD and NADP, the 
Table 2. Conserved residues and motifs in the structure of sulphite reductase flavoprotein from $T$. roseopersicina

\begin{tabular}{|c|c|c|}
\hline Cofactor domain* & Position & Conserved residuest \\
\hline FMN phosphate & $59-78$ & RITILFGSQTGNAKAVAEQL \\
\hline $\mathrm{FMN}$ ring $(S i)$ & 109-131 & LIVVSIHGEGEPPENAY YLHAFL \\
\hline $\mathrm{FMN}$ ring $(R e)$ & $139-157$ & LEQLPFAVLGLGDSSYEHF \\
\hline FAD ring $(S i)$ & $441-343$ & $\underline{L} \underline{\text { HPTTVRGWSRAS }}$ \\
\hline $\mathrm{FAD}$ ring $(R e)$ & $515-522$ & ECIATDDDL \\
\hline FAD adenine & $344-352$ & $\underline{\text { GRTGAEDA }}$ \\
\hline FAD pyrophosphate & $353-360$ & ERLEEREEQ \\
\hline NADPH pyrimidine & $451-488$ & 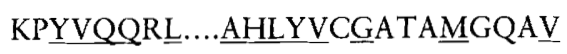 \\
\hline NADPH pyrophosphate & $381-400$ & LIMIGAGTGV APYRAFLQQR \\
\hline
\end{tabular}

"Definition according to Wang et al. (1997).

†Underlining indicates residues identical to E. coli cysJ.

Table 3. Conserved residues and motifs in the structure of sulphite reductase haemprotein from $T$. roseopersicina

\begin{tabular}{|c|c|c|}
\hline Function* & Amino acid type & Conserved residues \\
\hline \multirow[t]{3}{*}{ Binding of sirohaem } & Basic & $\begin{array}{l}\text { R73, R103, R107, Q111, H113, K215, K207, } \\
\text { R204, Q385, R474 }\end{array}$ \\
\hline & Hydrophilic & $\mathrm{T} 105, \mathrm{~T} 428$ \\
\hline & Aliphatic & $\mathrm{V} 425$ \\
\hline $\begin{array}{l}\text { Substrate interaction on } \\
\text { distal side of haem }\end{array}$ & Positively charged & R73, R107, R142, R204, K205, K207 \\
\hline $\begin{array}{l}\text { Binding of } \mathrm{Fe}_{4}-\mathrm{S}_{4} \text { and } \\
\text { bridging ligand }\end{array}$ & Cysteine groups & CVXXTC429PL, GCPNGC472 \\
\hline
\end{tabular}

"Definition according to Crane et al. (1996, 1997).

isoalloxazin ring-binding motif of FMN, and the binding motifs of FAD and NADP as described by Wang et al. (1997), are fully conserved (Table 2).

An alternative $\mathrm{N}$-terminus for the flavoprotein is predicted by the ORF-finder option from the cysJ DNA sequence. The protein is extended by 38 amino acids, resulting in a total length of 560 residues with a molecular mass of $62127 \mathrm{Da}$. If translation of the putative cysJ homologue starts at A492TG the CysJ polypeptide would be extended by a pre-sequence containing mainly positively charged amino acids like arginine that could interact with the negatively charged phospholipids of the cytoplasmic membrane.

cysI encodes the sulphite reductase haem protein consisting of 559 amino acid residues with a molecular mass of $62279 \mathrm{Da}$. It is $54 \%$ identical to the $\beta$ subunit of $E$. coli NADPH-sulphite reductase. The polypeptide sequence $\mathrm{NH}_{2}$-TGCPNGCAR474-COOH extracted from a multiple alignment of sulphite reductases from E. coli, S. typhimurium, Synechococcus and the nitrite reductase in order to design a DNA probe was fully conserved at a corresponding position in the Thiocapsa haemprotein. In combination with the cysteines of the motif CVALPTC429 the cysteines in this sequence form covalent bonds with the Fe groups of the iron-sulphur cluster, while cysteine $\mathrm{C} 472$ serves as bridging ligand between the $\mathrm{Fe}_{4}-\mathrm{S}_{4}$ cluster and the $\mathrm{Fe}$ of the sirohaem. In addition to the cysteine clusters, the 15 amino acid residues that were proposed to bind the sirohaem are identical with the exception of LS259 of E. coli, which are replaced by TG247 in the Thiocapsa sequence. And secondly, the set of positively charged amino acids facing the distal anion-binding site of the haem is fully conserved (Table 3).

A catalytic function of the putative NADPH-sulphite reductase was demonstrated by phenotypic complementation of cys mutants deficient in flavo- and haem protein of sulphite reductase and by in vitro testing of the MVH-dependent formation of sulphide from sulphite. A complementation of the haemprotein-deficient cysI mutant of $E$. coli was observed with plasmids pTH6, 11 and 12, which contained the cysI fragment from $T$. roseopersicina. However, none of the constructs 
containing also cysJ was able to complement the flavoprotein-deficient E. coli mutant (Fig. 1). pTH13 contained, in addition to cysl and the truncated cysJ genes, a complete $c y s G$ gene from $S$. typhimurium in order to increase the content of sirohaem (Wu et al., 1991). Expression of the cysI gene from pTH13 in JM246 was verified by Western immunoblotting (data not shown). The size of $62 \mathrm{kDa}$ corresponds to that predicted from the amino acid sequence. The cysI mutant complemented with pTH13 was tested for the occurrence of an active sulphite reductase haem protein using $\mathrm{MVH}$ as reductant. The activity of the recombinant Thiocapsa enzyme was hardly detectable $[0.9 \mathrm{mU}$ (mg protein $)^{-1}$ ] and considerably lower than that of homologous recombinant sulphite reductase (65 $\mathrm{mU} \mathrm{mg}^{-1}$ ) expressed from pJYW609 with the authentic cysJI genes from E. coli. NADPH-sulphite reductase activity was not detectable in vitro from $E$. coli JM246 transformed with pTH13 but complementation of this mutant is seen as circumstantial evidence for its existence in vivo. The protein was enriched by ammonium sulphate precipitation and chromatography on a DEAE-cellulose column. A specific activity of $38.5 \mathrm{mU} \mathrm{mg}^{-1}$ was obtained from combined fractions of the DEAE-cellulose fractionation using $\mathrm{MVH}$ as reductant. The rate represented a 42 -fold enrichment over the crude cell extract.

CysH: PAPS reductase. Translation of the cysH ORF yields a polypetide of 239 amino acids with a molecular mass of $27697 \mathrm{Da}$. Its amino acid sequence is $63.7 \%$ identical to the $c y s H$ gene product from E. coli representing the enzyme PAPS reductase. The $T$. roseopersicina PAPS reductase homologue is also highly related to the PAPS reductases from the cyanobacteria Synechococcus and Synechocystis and more distantly related to the PAPS reductases from fungi (Saccharomyces cerevisiae and Schizosaccharomyces pombe). The putative PAPS reductase from the purple bacterium together with the aforementioned PAPS reductases belongs to a larger family of homodimeric PAPS reductases that do not contain (a) chromophore(s) but use reduced thioredoxin or glutaredoxin as reductant. A hallmark of this type of PAPS reductase is the cysteine motif ECGL/IH located near the Cterminus (Berendt et al., 1995). In the active dimer two cysteine residues form a redox-active dithiol-disulphide. In addition to this cysteine motif, $T$. roseopersicina PAPS reductase also contained the GYxS/TI/VG motif with Y205 and a highly flexible loop rich in basic amino acids GxRR/KxQ with a flexible arginine residue. As deduced from the three-dimensional structure (Savage $e t$ al., 1997) the arginine together with the DTG and SFG motifs form the active centre of PAPS reductase.

E. coli JM96 transformed with pTH5 regained its prototrophic growth, exhibiting a specific activity of $0.7 \mathrm{mU} \mathrm{mg}^{-1}$ measured as sulphite formed from PAPS with heterologous $E$. coli thioredoxin as reductant. The activity found in cell extracts was comparable to that of wild-type $E$. coli grown on sulphate. However, as JM96 $6_{\mathrm{FAK}}$ expressing $T$. roseopersicina cysH formed

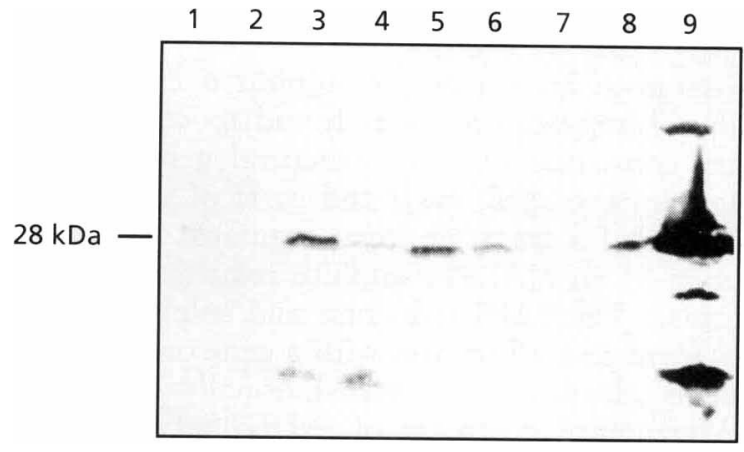

Fig. 3. Immunological detection of native PAPS reductase from $T$. roseopersicina M1: Western immunblot of cell extracts from bacteria (10 mg wet weight) grown as batch cultures, tested with monospecific antibodies against PAPS reductase from $T$. roseopersicina. (1) Photoautotrophic growth $2 \mathrm{~d}$ after feeding $\mathrm{H}_{2} \mathrm{~S} / \mathrm{CO}_{2} ;(2)$ as (1), but cells extracted $7 \mathrm{~d}$ after feeding $\mathrm{H}_{2} \mathrm{~S} / \mathrm{CO}_{2}$. Cells from (2) were used to inoculate cultures (4), (6) and (8) $(20 \%, v / v)$ (termed plus $\left.\mathrm{SO}_{4}^{2-}\right)$, while (3), (5) and (7) were washed in $2.5 \% \mathrm{NaCl}$ before inoculation to remove inorganic sulphate of the pre-culture (termed minus $\mathrm{SO}_{4}^{2-}$ ), (3) Phototrophic growth in the presence of organic carbon (see Methods), minus $\mathrm{SO}_{4}^{2-}$; (4) phototrophic growth as in (3), plus $\mathrm{SO}_{4}^{2-} ;$ (5) organoheterotrophic growth in the presence of organic carbon, dark, minus $\mathrm{SO}_{4}^{2-} ;(6)$ organoheterotrophic growth as in (5), plus $\mathrm{SO}_{4}^{2-} ;$ (7) organoheterotrophic growth as semioxic culture using Erlenmeyer shake flasks sealed with foam plastic plugs, supplemented with $\mathrm{S}_{2} \mathrm{O}_{3}^{2-} / \mathrm{CO}_{2}$, minus $\mathrm{SO}_{4}^{2-}$; (8) organoheterotrophic growth as in (7), plus $\mathrm{SO}_{4}^{2-}$, but $\mathrm{S}_{2} \mathrm{O}_{3}^{2-}$ omitted; (9) recombinant PAPS reductase, clone $\mathrm{PQEH}$ as expressed in E. coli JM96 ${ }_{\mathrm{FAK}}$.

inclusion bodies, we compared the amount of readily extractable PAPS reductase with the amount of recombinant protein solubilized in the presence of $3 \mathrm{M}$ urea by Western immunoblotting using polyclonal antibodies against PAPS reductases from $T$. roseopersicina and antibodies against PAPS reductase from $E$. coli (data not shown). The recombinant PAPS reductase was detectable at a position in the gel which corresponded to a molecular mass of $28 \mathrm{kDa}$. This is in good agreement with the size predicted from the amino acid composition of the $c y s H$ gene product from $T$. roseopersicina. The amount of soluble PAPS reductase detectable in the immunblot decreased early at the beginning of the exponential growth phase when the cell density surpassed $\mathrm{OD}_{595} 0 \cdot 2-0 \cdot 3$. Only traces of soluble protein were found in the late-exponential phase $\left\langle\mathrm{OD}_{595} \leqslant 0 \cdot 7\right)$ falling below detectability in the stationary phase $\left(\mathrm{OD}_{595}\right.$ $\geqslant 1.5)$. A background caused by PAPS reductase from the host can be excluded because $E$. coli anti-PAPS reductase did not cross-react with PAPS reductase antigen from $T$. roseopersicina.

In Western immunoblots of cell extracts, native PAPS reductase in $T$. roseopersicina was only detected when the source of sulphur was manipulated (Fig. 3, lanes 3, 4, 5 and 8$). c y s \mathrm{H}$ appeared to be derepressed when sulphate as supply of sulphur became limiting. In the presence of $\mathrm{S}_{2} \mathrm{O}_{3}^{2-}$ (lane 7) PAPS reductase became undetectable, implying that its biosynthesis was downregulated by this sulphur source in $T$. roseopersicina. 


\section{DISCUSSION}

T. roseopersicina - a purple sulphur bacterium of the family Chromatiaceae - was found to contain a gene cluster consisting of four structural genes that were homologous to $c y s B, c y s J I$ and $c y s H$ of enterobacteria and encoded a transcriptional regulator protein, both subunits of an NADPH-sulphite reductase, and PAPS reductase. The PAPS reductase and sulphite reductase genes form a small operon with a gene order of cys $J 1 H$ which is assumed to be translationally coupled. The DNA structure upstream of $c y s J I H$ includes a homologue of the gene for the transcriptional regulator CysB, which is transcribed in the opposite direction. $c y s B$ and $c y s J 1 H$ are separated by a short intergenic region that could serve as target for the CysB protein overlapping the putative promoter of $c y s J . T$. roseopersicina $\mathrm{CysB}$ has $40 \%$ identical and $80 \%$ similar amino acids when compared with CysB from $S$. typhimurium. An identical function would imply that the CysB gene product autoregulates its synthesis and in addition, due to the very short distance between the $c y s B$ promoter and the promoter of the cys $J 1 H$ gene, CysB as repressor would also control the transcription of the adjacent $c y s J 1 H$ genes. In enterobacteria, CysB controls the expression of $c y s B$ negatively as a true repressor whereas for expression of the $c y s J I H$ cluster it can also serve as transcriptional activator when it binds $N$ acetyl-L-serine (Kredich, 1993). By binding sulphide or thiosulphate it acts as repressor and sulphide or thiosulphate acts as co-repressor. Hryniewicz \& Kredich (1995) observed that in S. typhimurium a single CysB protein tetramer covers the DNA from -34 to -72 of the cys $J$ promoter. Addition of $N$-acetyl-L-serine as inducer extended the DNA-binding region from -32 to +17 , defining an additional accessory site that interacted with the protein. Projection of the footprints on an open cylinder showed that they form two adjacent sites, and binding of the two adjacent sites by CysB will probably cause the DNA to bend. The CysB DNAbinding site of $S$. typhimurium was $40 \mathrm{bp}$ in length as defined by DNase I footprinting. In this respect, it seems noteworthy that the binding motifs found in the cysK2 and $c y s B$ promoter regions of $E$. coli (Monroe et al., 1990 ) and of Klebsiella aerogenes (K. pneumoniae) (Lynch et al., 1994) are very similar with a sequence found in the promoter region of Thiocapsa cysB (Fig. 4).

Structural and mutational analysis of LysR-type regulator proteins indicated a structure consisting of a

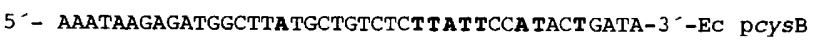

5 - GAAACAGGGGTGGCTTATGCCGCCCCTtATtCCA TCTTGCAT-3 - -St pCysK2

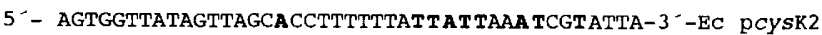

3- ${ }_{461}$ GGTCCGAGACGATTTGAAATGACCATTTATGCGTTATCACGG ${ }_{418}-5^{-}$-Tr pCysB

consensus $\quad$ TtaTt aT $t$
}

Fig. 4. Sequence comparison of the $c y s K 2$ and $c y s B$ promoter regions of $E$. coli $(\mathrm{EC}), S$. typhimurium $(\mathrm{St})$ and $T$. roseopersicina $(\mathrm{Tr})$. helix-turn-helix DNA-binding motif (residues 6-66) located at the N-terminus. As shown for the Klebsiella CysB protein, residues 88-324 of the structure fold into two $\alpha / \beta$ domains that are connected by two short segments of polypeptide (Tyrrell et al., 1997). The two domains form a substrate-binding cavity which is lined by P31, T100, T102, Q103, T149, E150, W166 and T202. T149, whose mutation caused constitutive expression (Colyer \& Kredich, 1994), and all the other residues listed are conserved in the CysB homologue of $T$. roseopersicina.

cysJIH of $T$. roseopersicina encodes sulphite reductase and PAPS reductase. These gene products were analysed by phenotypic complementation and in vitro as recombinant enzymes. Of the two sulphite reductase mutants from E. coli, cysI was complemented by plasmids encoding either sulphite reductase holoenzyme or the sulphite reductase sirohaem subunit alone. The mutant with a defect in the flavoprotein subunit was not complemented by the homologous gene product from $T$. roseopersicina, but cumulative data from sequence alignments with NADPH:cytochrome P450 oxidoreductases and the known enterobacterial NADPHsulphite reductases strongly implied that the enzyme is an NADPH-dependent sulphite reductase. This type of assimilatory sulphite reductase is composed of the two subunits that contain in the $\alpha$ subunit FAD and FMN as prosthetic groups and in the $\beta$ subunit the $\mathrm{Fe}_{4}-\mathrm{S}_{4}$ cluster and the sirohaem.

The flavoprotein contained all the structural elements that have been defined most recently for the $\mathrm{NAD}(\mathrm{P}) \mathrm{H}$ : cytochrome $\mathrm{P} 450$ oxidoreductases. The close relation of $T$. roseopersicina flavoprotein moiety to the NADPH: cytochrome P450 oxidoreductases is indicated by its relative shorter distance in the unrooted phylogenetic tree, where it branches closer from the mammalian homologues than from the plant-type NADPH:cytochrome P450 oxidoreductases. With one exception, all residues suggested to form the FMNbinding domains and the FAD-NADP-binding pocket are conserved (Wang et al., 1997). As in the E. coli sulphite reductase flavoprotein, only the inner ringshielding tyrosine (Y154) is conserved while the exterior FMN-shielding tyrosine (Y115) is replaced by a histidine (see Table 2).

In an unrooted phylogenetic tree, sulphite reductase haem protein from $T$. roseopersicina is grouped together with the two haem proteins from enterobacteria. The group of bacterial haem proteins differ considerably from the fungal haem proteins of Sacch. cerevisiae and Schiz. pombe, which form a small group of eukaryotic NADPH-dependent sulphite reductases. The ferredoxin-dependent sulphite reductases are also related to the NADPH-dependent enzymes but, presumably due to the different electron donor, they form an individual third group of haem proteins. Ferredoxin nitrite reductases from higher plants and cyanobacteria were found as closest relatives whereas dissimilatory sulphite reductases appear as non-related using the search algorithms of Altschul et al. (1997). 
A structural gene encoding PAPS reductase was not expected as Schmidt \& Trüper (1977) observed sulphite formation in Chromatium vinosum, $T$. roseopersicina and T. pfennigii showing a 10-fold preference for adenylylsulphate (APS) versus PAPS, suggesting that an APS-sulphotransferase rather than thioredoxin-PAPS reductase occurred in these species of the Chromatiaceae and in Rhodospirillum rubrum. To date, only a structural gene related to $c y s H$ from enterobacteria rather than the plant-type GSH-dependent APS-reductase has been found in $T$. roseopersicina. PAPS reductase activity, however, was virtually undetectable from cells grown under photolithoautotrophic conditions, as the enzyme is expected to be down-regulated in the presence of sufficient supplies of sulphur. In this respect $T$. roseopersicina seems to control the enzymes of the assimilatory pathway like E. coli or S. typhimurium. Hence, sulphite formation from APS by APS sulphotransferase activity as observed by Schmidt \& Trüper (1977) may have been produced by APS reductase, which is also present in Chromatiaceae (Dahl \& Trüper, 1994).

The occurrence in $T$. roseopersicina of a sulphite reductase which is homologous to the assimilatory $\mathrm{NADPH}$-dependent enzyme from enterobacteria does not exclude the possibility that the organism, like the closely related Chromatium vinosum, contains a dissimilatory sulphite reductase in addition to its assimilatory enzyme. Based on $16 \mathrm{~S}$ rRNA cataloging and $5 \mathrm{~S}$ rRNA sequence comparison (cited by de Ley, 1992), $T$. roseopersicina belongs to the family Chromatiaceae, which forms a phylogenetically coherent cluster with a binary matching coefficient $\left(S_{\mathrm{AB}}\right)$ of 0.66 . In this context it is noteworthy that the oligonucleotide R3 that was used here to detect the $T$. roseopersicina cysl gene also gave similar hybridization signals with genomic DNA from C. vinosum digested with Bam HI (Haverkamp, 1992). C. vinosum was reported to contain the structural genes of a dissimilatory sulphite reductase (Hipp et al., 1997) with a high homology to $d s r / d s v$ genes from Desulfovibrio vulgaris and Archaeoglobus fulgidus respectively (Dahl et al., 1993; Karkhoff-Schweizer et al., 1995). As the polypeptides deduced from these $C$. vinosum genes give subunits of 46.8 and $39.9 \mathrm{kDa}$, which would be in good agreement with the subunit size of the reverse sulphite reductase described by Schedel et al. (1979), the authors suggested that dissimilatory sulphite reductase is the enzyme responsible for reverse sulphite reductase activity in C. vinosum. The finding that reverse sulphite reductase activity was only detected in $C$. vinosum grown autotrophically on hydrogen sulphide, but not in extracts from cells grown photoheterotrophically with malate and sulphate, does not conflict with the activity of an assimilatory sulphite reductase. As this type of enzyme appears to be under control of the CysB regulator it is expected to be detectable only when the supply of sulphur becomes limiting.

\section{ACKNOWLEDGEMENTS}

Thiocapsa roseopersicina 6311 was a kind gift of H. G. Trüper, Microbiology \& Biotechnology, University of Bonn; $T$. roseopersicina $\mathrm{M} 1$ was kindly provided by $H$. van Gemerden, RU Groningen; and cys mutants of $E$. coli were obtained from B. Bachmann, ECGSC, Yale. We wish to thank G. Gisselmann, Bochum, for his many helpful suggestions in setting up the PCR methods and C. Jakobs, Bonn, and J. Imhoff, Kiel, for their indispensable advice concerning the growth requirements of sulphur oxidizers. We are also indebted to N. M. Kredich and J. Y. Wu, Duke University, Durham, NC, for their gift of the cysG plasmid.

The financial support of the Deutsche Forschungsgemeinschaft, Bonn, is gratefully acknowledged.

\section{REFERENCES}

Altschul, S. F., Madden, T. L., Schaffer, A. A., Zhang, J., Zhang, Z., Miller, W. \& Lipman, D. J. (1997). Gapped BLAST and PSI-BLAST: a new generation of protein database search programs. Nucleic Acids Res 25, 3389-3402.

Berendt, U., Haverkamp, T., Prior, A. \& Schwenn, J. D. (1995). Reaction mechanism of thioredoxin: $3^{\prime}$-phospho-adenylylsulfate reductase investigated by site-directed mutagenesis. Eur $J$ Biochem 233, 347-356.

Bradford, M. M. (1976). A rapid and sensitive method for the quantitation of microgram quantities of protein utilizing the principle of protein-dye binding. Anal Biochem 72, 248-254.

Brühl, A., Haverkamp, T., Gisselmann, G. \& Schwenn, J. D. (1996). A cDNA clone from Arabidopsis thaliana encoding plastidic ferredoxin:sulfite reductase. Biochim Biophys Acta 1295, 119-124.

Catty, D. \& Raykundalia, C. (1988). Polyclonal antibodies. In Antibodies, vol. 1, pp. 19-79. Edited by D. Catty. Oxford: IRL Press.

Colyer, T. E. \& Kredich, N. M. (1994). Residue threonine-149 of the Salmonella typhimurium CysB transcription activator: mutations causing constitutive expression of the positively regulated genes of the cysteine regulon. Mol Microbiol 13, 797-805.

Crane, B. R. \& Getzoff, E. D. (1996). The relationship between structure and function for the sulfite reductases. Curr Opin Struct Biol 6, 744-756.

Crane, B. R., Siegel, L. M. \& Getzoff, E. D. (1995). Sulfite reductase structure at $1.6 \AA$ : evolution and catalysis for reduction of inorganic anions. Science 270, 59-67.

Crane, B. R., Siegel, L. M. \& Getzoff, E. D. (1997). Probing the catalytic mechanism of sulfite reductase by X-ray crystallography: structures of the Escherichia coli hemoprotein in complex with substrates, inhibitors, intermediates, and products. Biochemistry 36, 12120-12137.

Dahl, C. \& Trüper, H. G. (1994). Enzymes of dissimilatory sulfide oxidation in phototrophic sulfur bacteria. Methods Enzymol 243, $400-421$.

Dahl, C., Kredich, N. M., Deutzmann, R. \& Trüper, H. G. (1993). Dissimilatory sulphite reductase from Archaeoglobus fulgidus: physicochemical properties of the enzyme and cloning, sequencing and analysis of the reductase genes. J Gen Microbiol 139, 1817-1828.

Friedrich, C. G. (1998). Physiology and genetics of sulfur-oxidizing bacteria. Adv Microb Physiol 39, 235-289. 
Gisselmann, G., Klausmeier, P. \& Schwenn, J. D. (1993). The ferredoxin:sulphite reductase from Synechococcus PCC7942. Biochim Biophys Acta 1144, 102-106.

Haverkamp, T. (1992). cys-homologe DNA in Schwefel oxidierenden Bakterien. Diploma thesis, Faculty of Biology, Bochum.

Haverkamp, T. (1996). Identifizierung und Charakterisierung eines cysBJIH-Regulons aus dem Purpurbakterium Thiocapsa roseopersicina $\mathrm{M} 1$. $\mathrm{PhD}$ thesis, Faculty of Biology, Bochum.

Hipp, W. M., Pott, A. S., Thum-Schmitz, N., Faath, I., Dahl, C. \& Truper, H. G. (1997). Towards the phylogeny of APS reductases and sirohaem sulfite reductases in sulfate-reducing and sulfuroxidizing prokaryotes. Microbiology 143, 2891-2902.

Hryniewicz, M. M. \& Kredich, N. M. (1995). Hydroxyl radical footprints and half-site arrangements of binding sites for the $c y s B$ transcriptional activator of Salmonella typhimurium. J Bacteriol 177, 2343-2353.

Kämpf, C. \& Pfennig, N. (1980). Capacity of Chromatiaceae for chemotrophic growth. Specific respiration rates of Thiocystis violacea and Chromatium vinosum. Arch Microbiol 127, 125-135.

Karkhoff-Schweizer, R. R., Huber, D. P. W. \& Voordouw, G. (1995). Conservation of the genes for dissimilatory sulfite reductase from Desulfovibrio vulgaris and Archaeoglobus fulgidus allows their detection by PCR. Appl Environ Microbiol 61, 290-296.

Kelly, D. P. (1990). Energetics of chemolithotrophs. In The Bacteria, vol. XII, Bacterial Energetics, pp. 479-503. Edited by T. A. Krulwich. New York: Academic Press.

Kelly, D. P., Shergill, J. K., Lu, W. P. \& Wood, A.P. (1997). Oxidative metabolism of inorganic sulfur compounds by bacteria. Antonie Leeuwenhoek 71, 1-2.

Kredich, N. M. (1993). Gene regulation of sulfur assimilation. In Sulfur Nutrition and Assimilation in Higher Plants, pp. 37-47. Edited by L. J. de Kok, I. Stulen, H. Rennenberg, C. Brunold \& W. E. Rauser. The Hague: SPB Academic Publishing.

Krone, F. A., Westphal, G. \& Schwenn, J. D. (1991). Characterisation of $c y s H$ and of its product phospho-adenylylsulfate reductase from Escherichia coli. Mol Gen Genet 225, 314-319.

Laemmli, U. K. (1970). Cleavage of structural proteins during the assembly of the head of bacteriophage T4. Nature 227, 680-685. de Ley, J. (1992). The Proteobacteria: ribosomal RNA cistron similarities and bacterial taxonomy. In The Prokaryotes, pp. 2111-2142. Edited by A. Balows, H. G. Trüper, M. Dworkin, W. Harder \& K.-H. Schleifer. New York: Springer.

Lynch, A. S., Tyrrell, R., Smerdon, S. J., Briggs, G. S. \& Wilkinson, A. J. (1994). Characterization of the CysB protein of Klebsiella aerogenes: direct evidence that $\mathrm{N}$-acetylserine rather than $\mathrm{O}$ acetylserine serves as the inducer of the cysteine regulon. Biochem J 299, 129-136.

Monroe, R. S., Ostrowski, M., Hryniewicz, M. \& Kredich, N. M. (1990). In vitro interactions of CysB protein with the cysK and cys JIH promoter regions of Salmonella typhimurium. J Bacteriol 172, 6919-6929.

Ostrowski, J., Wu, J. Y., Rueger, D. C., Miller, B. E, Siegel, L. M. \& Kredich, N. M. (1989a). Characterization of the cys JIH regions of Salmonella typhimurium and Escherichia coli B. J Biol Chem 264, 15726-15737.

Ostrowski, J., Barber, B. E., Rueger, D. C., Miller, B. E., Siegel, L. M. \& Kredich, N. M. (1989b). Characterization of the flavo- protein moieties of NADPH-sulfite reductase from Salmonella typhimurium and Escherichia coli. J Biol Chem 264, 1579615808.

Pfennig, N. \& Trüper, H. G. (1992). The family Chromatiaceae. In The Prokaryotes, 2nd edn, pp. 3200-3221. Edited by A. Balows, H. G. Trüper, M. Dworkin, W. Harder \& K.-H. Schleifer. New York: Springer.

Sambrook, J., Fritsch, E. F. \& Maniatis, T. (1989). Molecular Cloning: a Laboratory Manual, 2nd edn. Cold Spring Harbor, NY : Cold Spring Harbor Laboratory.

Sanger, F., Nicklen, S. \& Coulson, A. R. (1977). DNA sequencing with chain terminating inhibitors. Proc Natl Acad Sci USA 74, 5463-5467.

Savage, H., Montoya, G., Svensson, C., Schwenn, J. D. \& Sinning, I. (1997). Crystal structure of phosphoadenylyl sulphate (PAPS) reductase: a new family of adenine nucleotide $\alpha$-hydrolases. Structure 5, 895-906.

Schedel, M., Vanselow, M. \& Trüper, H. G. (1979). Siroheme sulfite reductase from Chromatium vinosum. Purification and investigation of some of its molecular and catalytic properties. Arch Microbiol 121, 29-36.

Schell, M. A. (1993). Molecular biology of the LysR family of transcriptional regulators. Annu Rev Microbiol 47, 597-626.

Schmidt, A. \& Trüper, H. G. (1977). Reduction of adenylylsulfate and 3'-phosphoadenylylsufate in phototrophic bacteria. Experientia 33, 1008-1009.

Schriek, U. \& Schwenn, J. D. (1984). Properties of the APS-kinase from Saccharomyces cerevisiae. Arch Microbiol 145, 32-38.

Schwenn, J. D. \& Jender, H. G. (1980). Reversed phase high performance liquid chromatography of adenine-nucleotides: application to the kinetics of an adenosine $3^{\prime}$-phosphate $5^{\prime}$ sulphatophosphate sulphotransferase from plants. J Chromatogr 193, 285-290.

Schwenn, J. D. \& Kemena, A. (1984). Expression of the plant sulphite reductase in cell suspension cultures from Catharanthus roseus L. Planta 160, 151-158.

Schwenn, J. D. \& Schriek, U. (1986). PAPS-reductase from Escherichia coli: characterization of the enzyme as probe for thioredoxins. Z Naturforsch 42c, 93-102.

Schwenn, J. D., Krone, F. A. \& Husmann, K. (1988). Yeast PAPSreductase: properties and requirements of the purified enzyme. Arch Microbiol 150, 313-319.

Siefert, E. \& Pfennig, N. (1984). Convenient method to prepare neutral sulfide solution for cultivation of phototrophic sulfur bacteria. Arch Microbiol 139, 100-101.

Siegel, L. M. (1965). A direct microdetermination for sulfide. Anal Biochem 11, 126-132.

Siegel, L. M. (1976). Biochemistry of the sulfur cycle. In Metabolic Pathways, vol. VII, Metabolism of Sulfur Compounds, pp. 217-286. Edited by D. M. Greenberg. New York: Academic Press.

Towbin, H., Staehelin, T. \& Gordon, J. (1979). Electrophoretic transfer of proteins from polyacrylamide gels to nitrocellulose sheets: procedure and some applications. Proc Natl Acad Sci USA 76, 4350-4354.

Tyrrell, R., Verschueren, K. H., Dodson, E. J., Murshudov, G. N., Addy, C. \& Wilkinson, A. J. (1997). The structure of the cofactorbinding fragment of the LysR family member, CysB: a familiar fold with a surprising subunit arrangement. Structure 5, 1017-1032. 
Vogel, H. J. \& Bonner, D. M. (1956). Acetyl-ornithinase of Escherichia coli: practical purification and some properties. J Biol Chem 218, 97-106.

Wang, M., Roberts, D. L., Paschke, R., Shea, T. M., Masters, B. S. \& Kim, J. J. (1997). Three-dimensional structure of NADPHcytochrome P450 reductase: prototype for FMN- and FADcontaining enzymes. Proc Natl Acad Sci USA 94, 8411-8416.
Wu, J. Y., Siegel, L. M. \& Kredich, N. M. (1991). High-level expression of Escherichia coli NADPH-sulfite reductase: requirement for a cloned $c y s G$ plasmid to overcome limiting siroheme cofactor. J Bacteriol 173, 325-333.

Received 22 May 1998; revised 17 August 1998; accepted 15 September 1998. 